\title{
Pengukuran Tingkat Kebisingan di Wilayah Kerja Dinas Lingkungan Hidup Kota Kayu Agung
}

\author{
Atina $^{1^{*}}$, Indah Safitri ${ }^{2}$ \\ ${ }^{1,2}$ Program Studi Fisika Fisika, FMIPA Universitas PGRI Palembang, \\ Palembang 30251, Indonesia \\ *e-mail: atina.salsabila@gmail.com
}

\begin{abstract}
Abstrak
Dinas Lingkungan Hidup (DLH) Kota Kayu Agung merupakan lembaga pemerintah yang memiliki kewenangan menyusun dan mengatur kebijakan di bidang lingkungan hidup di wilayah Kabupaten Ogan Komering Ilir (OKI). Lokasi perkantoran DLH yang terletak di tepi jalan dan berdekatan dengan sekolah menyebabkan kemungkinan terjadinya kebisingan di lokasi ini. Tujuan penelitian ini adalah untuk mengukur tingkat kebisingan di lokasi kantor DLH, hasil penelitian dapat dijadikan acuan bagi DLH sendiri dalam menetapkan kebijakan lingkungan. Pembacaan data dilakukan dengan direct reading pada Sound Level Meter (SLV), kemudian dihitung nilai Leq sebagai kebisingan terukur untuk setiap waktu pengukuran. Leq dibandingkan dengan NAB untuk daerah perkantoran. Dari penelitian diperoleh rentang Leq pada L1 yaitu 57,6 62,9 dB(A), L2 antara 58,4 - 65,0 dB(A) dan L3 antara 59,4 - 62,3 dB(A). Dengan demikian dapat disimpulkan bahwa lokasi perkantoran DLH tidak bising dengan merujuk pada $\mathrm{NAB}$ yang ditetapkan pemerintah sesuai peraturan menteri lingkungan hidup no 48 tahun 1996 yaitu $65 \mathrm{~dB}(\mathrm{~A})$.
\end{abstract}

Kata Kunci: perkantoran, kebisingan, Sound Level Meter, NAB

\section{Noise Level Measurement in the Work Area of the Kayu Agung City Environmental Department Office}

\begin{abstract}
The Kayu Agung City Environmental Department (DLH) is a government agency that has the authority to compile and regulate environmental policies in the Ogan Komering Ilir (OKI) Regency. The location of the DLH office building located on the side of the road and close to the school causes the possibility of noise at this location. This study aims to measured the level of noise at the DLH office location, the results of the study can be used as a reference for DLH itself in setting environmental policies. Data reading has been done by reading directly on Sound Level Meter (SLV), then the Leq value is calculated as measured noise for each measurement time. Leq compared to NAV for office areas. From the research, the Leq range in $L 1$ is $57.6-62.9 d B(A), L 2$ is between $58.4-65.0 d B(A)$ and $L 3$ is between $59.4-62.3 d B(A)$. Thus it can be concluded that the location of DLH offices is not noisy by referring to the NAV determined by the government in accordance with the Minister of Environment Regulation No. 48 of 1996 which is $65 \mathrm{~dB}(\mathrm{~A})$.
\end{abstract}

Keywords: office area, noise, Sound Level Meter, NAV

PENDAHULUAN

Gelombang bunyi pada dasarnnya adalah perambatan energi dari sumber bunyi melalui suatu medium perambatan. Energi gelombang bunyi yang menembus permukaan tiap satu satuan luas per detik dinyatakan dengan intensitas bunyi. 
Sedangkan taraf intensitas bunyi dinyatakan dalam desibel (dB). Pengukuran intensitas bunyi secara matematis dinyatakan dengan persamaan

$$
T I=10 \log \frac{I}{I_{0}}
$$

Keterangan :

$$
\begin{array}{ll}
\mathrm{TI} & =\text { Taraf Intensitas bunyi }(\mathrm{dB}) \\
\mathrm{I} & =\text { Intensitas bunyi }(\mathrm{dB}) \\
\mathrm{I}_{0} & =\text { Intensitas ambang pendengaran } \\
& \text { manusia }(\mathrm{dB})
\end{array}
$$

Persamaan (1) menyatakan bahwa taraf intensitas bunyi adalah logaritma perbandingan antara intensitas bunyi dengan intensitas ambang pendengaran manusia. Dimana intensitas ambang pendengaran manusia sebesar $10^{-12}$ $\mathrm{W} / \mathrm{m}^{2}$. Intensitas ambang pendengaran yaitu batas intensitas terendah yang dapat didengar manusia secara normal. Sedangkan intensitas tertinggi yang dapat didengar manusia tanpa rasa sakit dikenal dengan intensitas ambang perasaan yaitu sebesar $1 \mathrm{~W} / \mathrm{m}^{2}$.

Intensitas bunyi yang terlalu tinggi dapat mengganggu pendengar baik secara psikis maupun psikologis. Karenanya, pemerintah melalui peraturan menteri kesehatan no 70 tahun 2016 mengatur Nilai Ambang Batas (NAB) kebisingan tergantung dari lamanya pajanan. Kebisingan didefinisikan sebagai suara/bunyi yang tidak diinginkan dan dapat mengganggu pendengar dengan intensitas melebihi nilai ambang batas.

Nilai Ambang Batas (NAB) kebisingan merupakan nilai yang mengatur tentang tekanan bising rata-rata atau level kebisingan berdasarkan durasi pajanan bising yang mewakili kondisi dimana hampir semua pekerja terpajan bising berulang - ulang tanpa menimbulkan gangguan pendengaran dan memahami pembicaraan normal (Kesehatan, 2016). Tabel 1 menunjukkan NAB untuk masing - masing area sesuai dengan Peraturan Menteri Kesehatan no 70 tahun 2016 dalam satuan $\mathrm{dB}(\mathrm{A})$.

Tabel 1. NAB Kebisingan (Baku Tingkat Kebisingan sesuai dengan Peruntukan)

\begin{tabular}{|l|c|}
\hline \multicolumn{1}{|c|}{$\begin{array}{c}\text { Peruntukan Kawasan/Lingkungan } \\
\text { Kegiatan }\end{array}$} & $\begin{array}{c}\text { Tingkat Kebisingan } \\
\mathrm{dB}(\mathrm{A})\end{array}$ \\
\hline Peruntukan Kawasan & 55 \\
\hline Perumahan dan pemukiman & 70 \\
\hline Perdagangan dan jasa & 65 \\
\hline Perkantoran dan perdagangan & 50 \\
\hline Ruang terbuka hijau & 70 \\
\hline Industri & 60 \\
\hline Pemerintahan dan fasilitas umum & 70 \\
\hline Rekreasi & 60 \\
\hline Khusus : Bandar Udara, Stasiun & \\
Kereta api, Pelabuhan Laut, & \\
Cagarr Budaya & 55 \\
\hline Lingkungan Kegiatan & 55 \\
\hline Rumah Sakit dan sejenisnya & 55 \\
\hline Sekolah dan sejenisnya & \\
\hline Tempat Ibadah dan sejenisnya &
\end{tabular}

Sumber : Kep Men LH No 48 tahun 1996

Kebisingan dapat diukur dengan menggunakan sound level meter (SLM). SLM telah banyak dikembangkan untuk berbagai instansi pengguna, baik digital maupun analog. SLM berbasis arduino juga telah banyak berkembang. Salah 
satunya dikembangkan oleh Nugroho (2019), prinsip kerja SLM berbasis arduino adalah gelombang bunyi yang dikeluarkan sumber bunyi ditangkap microphone sensor akan menyebabkan difragma pada microphone dan kumparan kawat dibelakangnya bergetar. Getaran ini menimbulkan arus bolak balik yang akan diolah oleh mikrokontroler sehingga menghasilkan taraf intensitas bunyi. Taraf intensitas bunyi inilah yang dinyatakan sebagai nilai kebisingan.

Hidayat (2015) menyatakan sumber bising utama dalam pengendalian bising lingkungan diklasifikan menjadi bising interior (berasal dari manusia, alat-alat rumah tangga, mesin dan aktifitas di dalam ruangan atau gedung) dan bising luar (bising yang dikategorikan dari aktifitas luar ruangan seperti transoprtasi udara, bus, mobil sepeda motor, transportasi air, kereta api dan bising yang berasal dari industri.

Penelitian sebelumnya yang membahas pengaruh kebisingan antara lain, Haurissa (2014) menyebutkan bahwa siswa dengan paparan bising 100 - 105 dB sebanyak 20\% dari sampel penelitian mengalami gangguan pendengaran. Marlina (2016) menyelidiki faktor risiko gangguan pendengaran dengan variabel ukur kebisingan, usia dan riwayat hipertensi. Dari ketiga faktor risiko diatas, kebisingan merupakan faktor yang paling berpotensi/berpengaruh terhadap gangguan pendengaran sensorineural pada pekerja PT. $X$ di Semarang. Sedangkan Septiana (2017) menyebutkan ada hubungan antara kebisingan, lama kerja dan umur dengan gangguan pendengaran akibat bising. Fanny (2015) menyatakan bahwa kebisingan berpengaruh terhadap tingkat konsentrasi kerja pada tenaga kerja di bagian produksi PT. Iskandar Indah Textile Surakarta.

$$
\text { Selain pada pendengaran, }
$$

kebisingan juga mempengaruhi psikologis pegawai seperti meningkatnya stress dan menurunkan semangat kerja. Hal ini akan berdampak pada kinerja karyawan. Dinas Lingkungan Hidup (DLH) kota Kayu Agung merupakan lembaga pemerintah yang memiliki kewenangan menyusun dan mengatur kebijakan di bidang lingkungan hidup di wilayah Kabupaten Ogan Komering Ilir (OKI). Dalam pelaksanaan tugasnya, DLH kota Kayu Agung melakukan berbagai upaya untuk melestarikan dan mengendalikan lingkungan. Salah satu upaya pengendalian lingkungan yaitu dengan pengukuran tingkat kebisingan di wilayah kerjanya. Kebisingan yang terlalu tinggi dan berlangsung dalam jangka waktu lama akan mempengaruhi kinerja pegawai.

Lokasi kantor DLH terletak ditepi jalan raya dan berdekatan dengan lokasi sekolah membuat lingkungan kerja di sekitar kantor padat/ramai khususnya di jam sibuk kendaraan yaitu pagi, siang dan sore hari. Kendaraan yang melintas dapat membuat suara bising yang memungkinkan terganggunya kinerja karyawan, karena itulah perlu dilakukan pengukuran tingkat kebisingan di lingkungan kantor DLH sendiri dengan demikian DLH dapat menjadikan hasil penelitian sebagai bahan pertimbangan dalam mengambil kebijakan lingkungan di daerah kerjanya. Fokus penelitian yaitu pada tingkat kebisingan yang disebabkan oleh faktor luar seperti kendaraan bermotor.

\section{BAHAN DAN METODE}

\section{a. Waktu dan Tempat}

Penelitian dilakukan pada bulan Desember 2019 selama 3 hari kerja berturut-turut dengan pengambilan data pada pagi (L1), siang (L2) dan sore (L3). Lokasi penelitian di lingkungan kerja Dinas Lingkungan Hidup Kota Kayu Agung dengan titik pengukuran sekitar 5 meter. Waktu pengambilan data masingmasing 10 menit dengan pembacaan data 
setiap 5 detik. Artinya dalam satu waktu pengambilan data diperoleh 120 data.

\section{b. Alat dan Bahan}

Pengukuran dilakukan dengan menggunakan sound level meter (SLV) digital. Screen pada SLV menunjukkan nilai kebisingan/bunyi yang tertangkap oleh sensor. Nilai inilah yang dibaca sebagai tingkat kebisingan terukur. Stopwatch digunakan untuk mengukur waktu. Subjek penelitian adalah kendaraan yang lalu lalang di sekitar lokasi penelitian.

\section{c. Metode dan Teknis Pengambilan Data}

Pembacaan data dengan direct reading pada screen SLV, dengan pengelompokan data menjadi 3 bagian yaitu:

$\mathrm{L}_{1}$ : Data sampling tingkat kebisingan pada pagi hari (jam 08.00 - 09.00 WIB).

$\mathrm{L}_{2}$ : Data sampling tingkat kebisingan pada siang hari (jam 12.00 - 13.00 WIB).

$\mathrm{L}_{3}$ : Data sampling tingkat kebisingan pada sore hari (jam 15.00-16.00 WIB).

Teknis pengambilan data diawali dengan survei penentuan titik pengukuran. Titik pengukuran didasarkan pada titik aman teknisi dengan tetap



a. mempertimbangkan jarak antara lokasi gedung kantor dengan jalan raya. Titik pengukuran dilakukan pada 1 titik tetap yaitu sekitar 5 meter dari tepi jalan.

d. Analisis

Analisis dilakukan dengan metode deskriptif. Analisis deskriptif bertujuan untuk menggambarkan kondisi dilapangan dengan penjelasan dan analisa yang didasarkan pada data hasil penelitian. Data penelitian diolah dengan mencari nilai eqivalen (Leq) untuk masing-masing waktu pengukuran. Leq dapat dihitung dengan :

$$
\text { Leq }=10 \log \left(\frac{1}{120} \sum_{1}^{120} 10^{\frac{L}{10}}\right) \mathrm{dB}(\mathrm{A})
$$

Leq adalah tingkat kebisingan eqivalen atau tingkat kebisingan terukur dari masing-masing waktu pengukuran dinyatakan dengan satuan $\mathrm{dB}(\mathrm{A})$. Nilai Leq ini selanjutnya dibandingkan dengan NAB yang ditetapkan pemerintah untuk daerah industri.

\section{HASIL DAN PEMBAHASAN}

Data hasil pengukuran disajikan dalam gambar berikut ini.

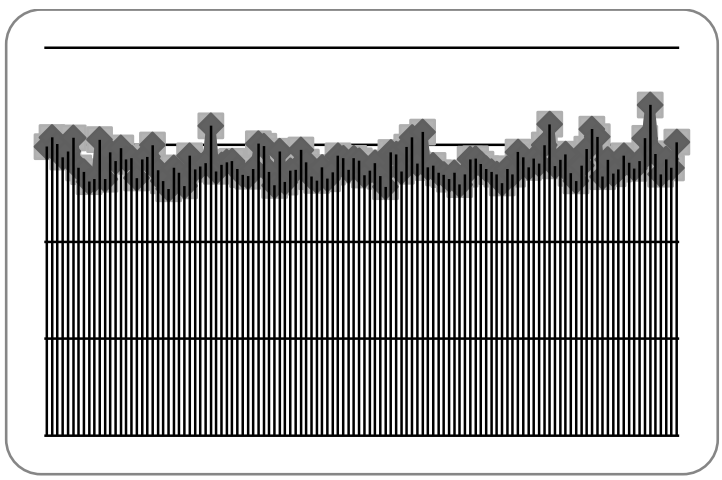

b. 




c.

Gambar 1. Pengukuran L1; a. Hari pertama; b. Hari kedua; c. Hari ketiga

Gambar 1 adalah hasil pengukuran pada L1, dimana Gambar 1a adalah pengukuran hari pertama dengan dengan interval $(54,2-74,7) \mathrm{dB}(\mathrm{A})$, Average : $(61,1) \mathrm{dB}(\mathrm{A}), \mathrm{L}_{\mathrm{eq}}=62,91006106 \mathrm{~dB}(\mathrm{~A})$. Gambar $1 \mathrm{~b}$ pengukuran pada hari kedua dengan Interval : $(50,9-68,2) \mathrm{dB}(\mathrm{A})$,

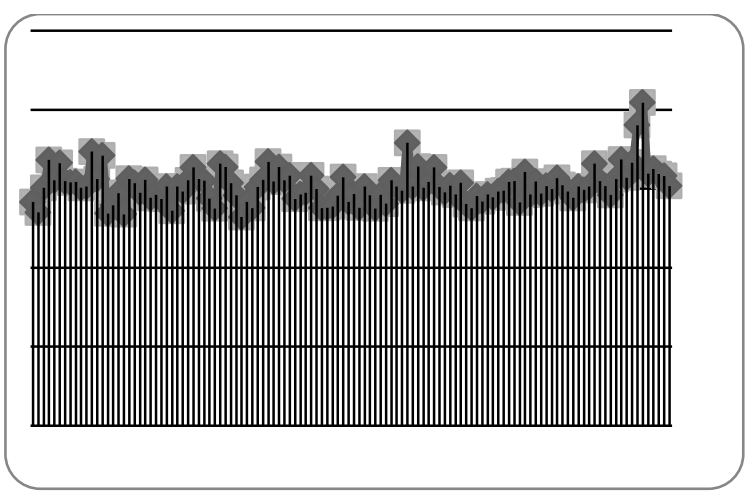

a.
Average: $(56,3) \quad \mathrm{dB} \quad(\mathrm{A}), \quad \mathrm{L}_{\text {aeq }}=$ 57,63599499 dB(A). Dan Gambar 1c adalah hasil pengukuran pada hari ketiga dengan Interval : $(52,6-70,6) \mathrm{dB}(\mathrm{A})$, Average : $(59,0) \quad \mathrm{dB} \quad(\mathrm{A}), \mathrm{L}_{\mathrm{aeq}}=$ 61,0983009 $\mathrm{dB}(\mathrm{A})$.

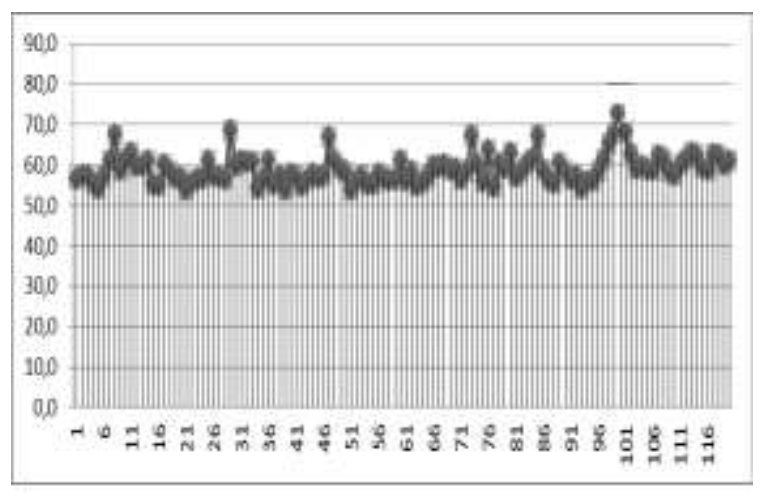

b.



c.

Gambar 2. Hasil Pengukuran L2; a. Hari pertama; b. Hari kedua; c. Hari ketiga

Gambar 2 adalah data hasil pengukuran untuk L2 pada tiga hari berturu-turut. Dimana Gambar 2a untuk pengukuran pada hari pertama dengan
Interval: $(52,8-81,8) \mathrm{dB}(\mathrm{A})$, Average : $(60,7) \quad \mathrm{dB} \quad(\mathrm{A}), \quad \mathrm{L}_{\mathrm{aeq}}=65,03246524$ $\mathrm{dB}(\mathrm{A})$. Gambar $2 \mathrm{~b}$ untuk pengukuran hari kedua dengan Interval : $(53,8-73,1)$ 
$\mathrm{dB}(\mathrm{A})$, Average : $(59,1) \mathrm{dB}(\mathrm{A}), \mathrm{L}_{\mathrm{aeq}}=$ 62,50270079 dB(A). Dan Gambar 3c untuk pengukuran hari ketiga dengan

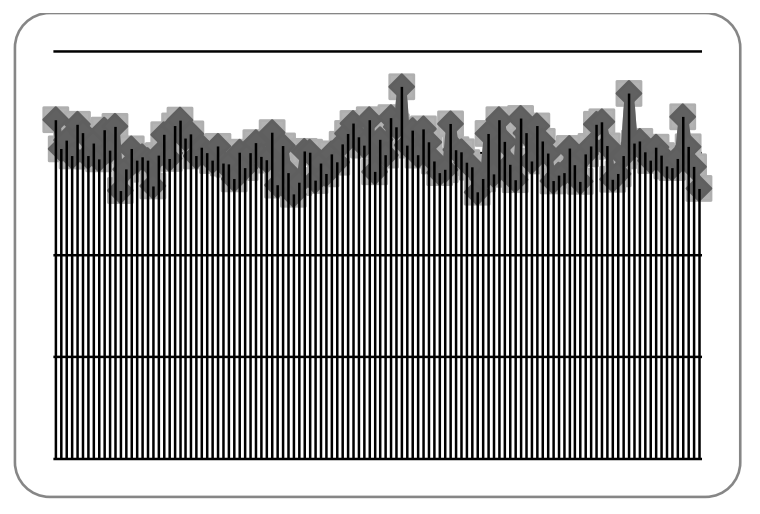

a.
Interval : $(50,7-71,0) \mathrm{dB}(\mathrm{A})$, Average : $(56,7) \mathrm{dB}(\mathrm{A}), \mathrm{L}_{\mathrm{aeq}}=58,37838764(\mathrm{~A})$.

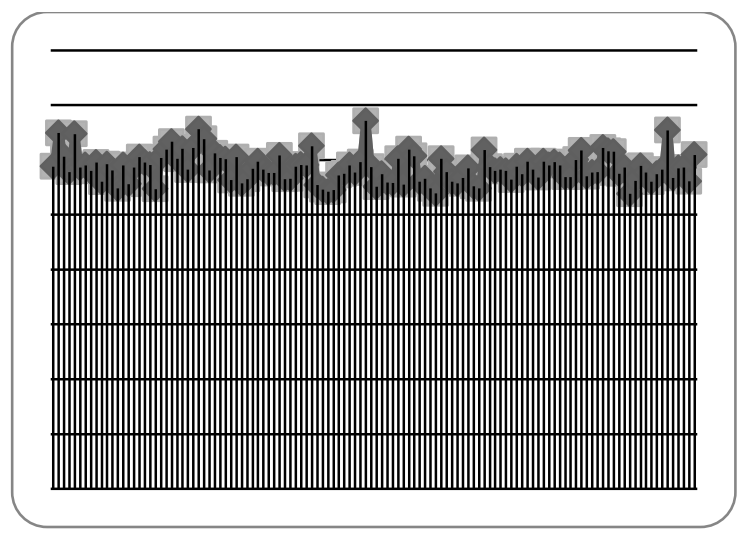

b.



c.

Gambar 3. Hasil Pengukuran L3; a. Hari pertama; b. Hari kedua; c. Hari ketiga

Gambar 3 adalah hasil pengukuran L3, dimana Gambar 3a untuk pengukuran pada hari pertama dengan Interval : (51,9 - 73,0) dB (A), Average : $(60,3) \mathrm{dB}(\mathrm{A})$, $\mathrm{L}_{\mathrm{aeq}}=62,30640723(\mathrm{~A})$. Gambar 3b untuk pengukuran pada hari kedua dengan Interval : $(53,8-67,1) \mathrm{dB}(\mathrm{A})$, Average : $(58,5) \quad \mathrm{dB} \quad(\mathrm{A}), \quad \mathrm{L}_{\mathrm{aeq}}=$ 59,44175552 (A). Dan Gambar 3c untuk pengukuran pada hari ketiga dengan Interval : $(51,9-71,3) \mathrm{dB}(\mathrm{A})$, Average :
$(57,9) \mathrm{dB}(\mathrm{A}), \mathrm{L}_{\mathrm{aeq}}=59,76320814(\mathrm{~A})$. Perhitungan Leq menggunakan persamaan (1) dimana Leq adalah nilai kebisingan terukur. Penulisan Leq pada penelitian ini disepakati dengan pembulatan 1 angka dibelakang koma, misalnya Leq $=62,91006106 \mathrm{~dB}(\mathrm{~A})$ maka ditulis menjadi Leq $=62,9 \mathrm{~dB}(\mathrm{~A})$. Tabel berikut adalah hasil perhitungan Leq untuk masing-masing waktu pengukuran.

Tabel 2. Leq untuk masing-masing waktu pengukuran

\begin{tabular}{|c|c|c|c|}
\hline \multirow{2}{*}{$\begin{array}{c}\text { Waktu } \\
\text { Pengukuran }\end{array}$} & \multicolumn{3}{|c|}{ Leq dalam $\mathrm{dB}(\mathrm{A})$ Hari ke- } \\
\cline { 2 - 4 } & 1 & 2 & 3 \\
\hline L1 & 62,9 & 57,6 & 61,1 \\
\hline L2 & 65,0 & 62,5 & 58,4 \\
\hline L3 & 62,3 & 59,4 & 59,8 \\
\hline
\end{tabular}

Data L1 dengan Leq terendah pada $57,6 \mathrm{~dB}(\mathrm{~A})$ yaitu hari kedua dan tertinggi pada hari pertama dengan Leq 62,9. Nilai Leq pada L1 jika dibandingkan dengan 
NAB untuk daerah perkantoran berada dibawa NAB yang ditetapkan pemerintah yaitu $65 \mathrm{~dB}(\mathrm{~A})$. Sehingga L1 dikatakan tidak bising. Data L2 dengan rentang Leq antara 58,4 $\mathrm{dB}(\mathrm{A})$ sampai $65,0 \mathrm{~dB}(\mathrm{~A})$.

L2 adalah pengukuran pada siang hari yaitu pada jam sibuk kendaraan. Lokasi titik pengukuran berdekatan dengan lokasi salah satu sekolah dan pada waktu pengukuran L2 khususnya hari pertama dan kedua bertepatan dengan jam pulang sekolah sehingga volume kendaraan terbilang cukup padat. Hal ini berbeda dengan L2 pada hari ketiga, hari ketiga adalah hari jum'at dimana jam pulang sekolah menjadi lebih awal sehingga pada saat pengukuran L2 volume kendaraan tidak sepadat hari sebelumnya. Dari Leq hari pertama di titik pengukuran digolongkan bising karena mencapai NAB, namun Leq pada hari berikutnya tergolong tidak bising. Jika merujuk pada gambar 2, Leq pada hari pertama tinggi karena adanya suara/sumber bunyi yang mencapai 81,8 $\mathrm{dB}(\mathrm{A})$ pada 2 menit terakhir pengukuran.

Gambar 3 menunjukkan data L3 dengan rentang Leq antara 59,4 $\mathrm{dB}(\mathrm{A})$ sampai 62,3 dB(A). Pada L3 terlihat bahwa rentang Leq berada dibawah NAB meskipun pada data pengukuran terdapat beberapa data yang mencapai diatas 65 $\mathrm{dB}(\mathrm{A})$, maun hal ini tidak membuat Leq menjadi tinggi karena frekuensi kendaraan dan jumlah data dengan hasil pengukuran tinggi hanya sedikit. Sehingga pada L3 digolongkan tidak bising dengan merujuk pada NAB untuk perkantoran.

Secara umum, Leq pada waktu titik pengukuran yaitu kantor Dinas Liingkungan Hidup kota Kayu Agung berada dibawah NAB yang ditetapkan pemerintah sesuai dengan Keputusan Menteri Lingkungan Hidup no 48 tahun 1996 yaitu untuk daerah perkantoran sebesar $65 \mathrm{~dB}(\mathrm{~A})$.

\section{KESIMPULAN}

Dari hasil penghitungan Leq dapat disimpulkan bahwa lokasi perkantoran Dinas Lingkungan Hidup kota Kayu Agung tergolong tidak bising karena Leq berada dibawah NAB yang ditetapkan pemerintah yaitu $65 \mathrm{~dB}(\mathrm{~A})$.

\section{DAFTAR PUSTAKA}

Djalante, S., Nurrakhmad, L. M., \& Sugiyarto, T. (2013). Simulasi Tingkat Kebisingan dan Kadar Polutan sebagai Akibat Aktivitas Transportasi pada Kawasan Perdagangan di Kota Kendari (Studi Kasus : Kawasan Perdagangan Jalan MT. Haryono Kec. Wua-wua Kota Kendari). Majalah Ilmiah MEKTEK Tahun ke-15 (2) , 59-81.

Fanny, N. (2015). Analisis Pengaruh Kebisingan terhadap Tingkat Konsentrasi pada Tenaga Kerja di Bagian Proses PT. Iskandar Indah Printing Textile Surakarta. Jurnal Ilmiah Rekam Medis dan Informatika Kesehatan Vol 5 No 1 , 52-61.

Haurissa, M. P., Mengko, S. K., \& Palandeng, O. I. (2014). Pengaruh Paparan Bising Terhadap Ambang Pendengaran Siswa SMK Negeri 2 Manado Jurusan Teknik Konstruksi Batu Beton. e-clinic, 2(1) .

Hidayat, R. W., Febriani, N., \& Ridhoni, A. (2015). Analisis Faktor-Faktor Kebisingan Komplek Perguruan Muhammadiyah di Kota Pekanbaru. Jurnal Photon Vol 6(1) , 61-71.

Hidup, K. L. (t.thn.). Keputusan Menteri Lingkungan Hidup No 48 tahun 1996. Jakarta, Indonesia: Kementerian Lingkungan Hidup.

Kesehatan, P. M. (2016). Standar dan Persyaratan Kesehatan Lingkungan Kerja Industri. Jakarta: Kementerian Kesehatan. 
Pengukuran Tingkat Kebisingan...Jupiter... Vol 1 No 2...Februari 2020...25-32 Atina, Indah Safitri

Marlina, S., Suwondo, A., \& Jayanti, S. (2016). Pengaruh Faktor Risiko Gangguan Pendengaran Sensorinural pada Pekerja PT. X Semarang. Jurnal Kesehatan Masyarakat (e-journal) Vol 4 No 1, 359-366.

Nugroho, P. C., \& Haj, M. I. (2019). Sound Level Meter Berbasis Arduino dengan Sensor Bunyi dan
Sensor Ultrasonic Untuk Menentukan Hubungan Jarak dengan Instensitas Bunyi. Seminar Nasional Pendidikan (Sendika) Vol. $3,117-124$.

Septiana, N. R., \& Widowati, E. (2017). Gangguan Pendengaran Akibat Bising. HIGEIA : Journal of Public Health Research and Development, 73-82. 